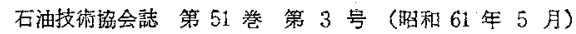

JOURNAL OF THE JAPANESE ASSOCIATION FOR PETROLEUM TECHNOLOGY

VOL. 51 , NO. 3 (May, 1986)

\title{
タイ沖ガス田における炭酸ガス起源の地質学的予察
}

\author{
佳々木 詔 雄* \\ （昭和61年1月18日受付，61年 3 月18日受理）
}

\section{Geological Studies on Origin of Carbon Dioxide in Platong Field, Gulf of Thailand \\ By}

Akio SASAKI

\begin{abstract}
In this paper, the distribution of carbon dioxide in natural gases recovered from the Platong gas field and its origin are discussed on the basis of geological evidences.

Carbon dioxide content in gases of this field is average $15 \%$ and partly more than $40 \%$.

Gas bearing Tertiary sediments are dominated by gas-prone woody-coaly organic matters. Main east-dipping faults in the western flank of this structure cut basement complex. Gas reservoirs containing rich carbon dioxide, more than $40 \%$, are locally distributed in the northwestern part of this field. The spatial spread is clearly oblique to stratigraphic markers and is like "conical mass". This mass is characterized by high density shale more than $2.70 \mathrm{gm} / \mathrm{cc}$ and very low $\mathrm{Cl}^{-}$content in formation water.

The above marked features suggest that carbon dioxide has been generated from woody-coaly kerogen in sediments during thermal diagenesis, and also has been supplied from "magmatic origin" through the faults, and/or formed by oxidation of hydrocarbons through contact with mineralized waters, which have ascended into Tertiary sediments along fractures and fault zones.
\end{abstract}

\section{1. はじめに}

天然ガスは, メタン・エタン・プロパンなどの各種崖
化水素のほか江不燃性ガスの炭酸ガス，窒素，硫化水素 を含み，極く微量に水素，アルゴン，ヘリウム，キ七， ンなどの存在が認められている。ほとんどの天然がスは

表 1 東南アジア地域の油・ガス田における天然ガ入の組成

\begin{tabular}{|c|c|c|c|c|c|c|c|}
\hline Country & \multicolumn{3}{|c|}{ Indonesia } & \multicolumn{2}{|c|}{ Malaysia } & \multirow{2}{*}{\multicolumn{2}{|c|}{$\frac{\text { Thailand }}{\text { Gulf of Thailand }}$}} \\
\hline Area & \multicolumn{2}{|c|}{ North Sumatra } & \multirow{2}{*}{$\frac{\text { Natuna }}{\text { D Alpha-L }}$} & \multirow{2}{*}{ Sarawak } & \multirow{2}{*}{$\frac{\mid \text { East Malaysia }}{\mid \text { Udang }}$} & & \\
\hline Field & Arun & NSB-A & & & & Erawan & Satun \\
\hline $\begin{array}{l}\text { Total } \\
\text { Hydrocarbon }\end{array}$ & $85.13 \%$ & $66.30 \%$ & $\mathrm{NA}$ & $91.5 \%$ & $\mathrm{NA}$ & $\mathrm{NA}$ & $90.49 \%$ \\
\hline $\mathrm{C}_{1}$ & 71.89 & 62.37 & $\mathrm{NA}$ & 86.2 & $85-98$ & $60-70$ & 74.10 \\
\hline $\mathrm{C}_{2}$ & 5.64 & 2.56 & NA & 2.4 & NA & $9-10$ & 9.70 \\
\hline $\mathrm{C}_{3}$ & 2.57 & 0.68 & $\mathrm{NA}$ & 1.3 & $\mathrm{NA}$ & $4-6$ & 3.77 \\
\hline $\mathrm{C}_{4}^{+}$ & 5.03 & 0.69 & $\mathrm{NA}$ & 1.6 & NA & $6-7$ & 2.92 \\
\hline $\begin{array}{l}\text { Total } \\
\text { Non-hydrocarbon }\end{array}$ & 14.87 & 33.87 & NA & 8.5 & $\mathrm{NA}$ & NA & 9.51 \\
\hline $\mathrm{CO}_{2}$ & $14.51^{\circ}$ & 31.10 & $67-82$ & NA & 1 & $10-20$ & 9.00 \\
\hline Reservoir & $\begin{array}{l}\text { Miocene } \\
\text { Carbonate }\end{array}$ & $\begin{array}{l}\text { Miocene } \\
\text { Carbonate }\end{array}$ & $\begin{array}{l}\text { Miocene } \\
\text { Carbonate }\end{array}$ & $\begin{array}{l}\text { Miocene } \\
\text { Carbonate }\end{array}$ & $\begin{array}{l}\text { Miocene } \\
\text { Carbonate }\end{array}$ & $\begin{array}{l}\text { Miocene } \\
\text { Carbonate }\end{array}$ & $\begin{array}{l}\text { Miocene } \\
\text { Carbonate }\end{array}$ \\
\hline Structure & Reef & . Reef & Reef & Reef & Anticline & Anticline & Anticline \\
\hline Refereances & $\begin{array}{l}\text { Bramon, } \\
1974\end{array}$ & Mundt, 1982 & $\begin{array}{r}\text { Sangree, } \\
1981 \\
\end{array}$ & Scherer, 1980 & $\begin{array}{|lc|}\text { Crossey et } \\
\text { al., } & 1982\end{array} \mid$ & $\begin{array}{r}\text { 世界の大油田 } \\
1985 \\
\end{array}$ & 佳々末，1985 \\
\hline
\end{tabular}

NA: Not Available 


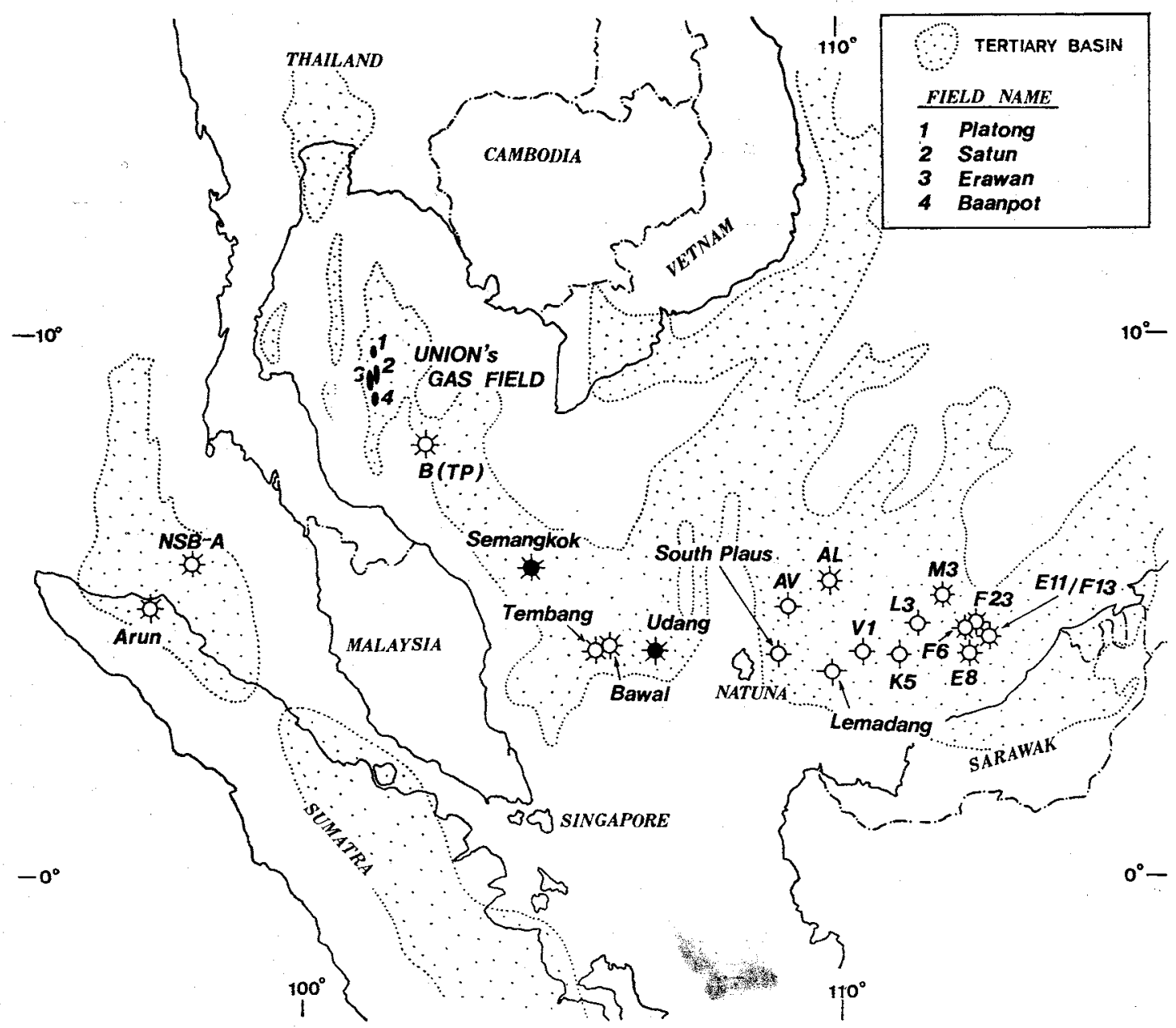

怄 1 東南乃ジア地域に括ける主要ガス田と第三系堆積䀂地の分布

含有量の多少にかかわらず炭酸がスを含有し，アメリカ 西部，メキシュ，カナダ，東南アジなどの一部のガス 田では比䡆的炭酸がス含有量の高い天然ガスが報告され ている(DOBBIN, 1968；加藤，1976)。

東南アジア地域における幾つかの油・ガス田の天然が ス組成を芫ると，孷酸ガスの含有量は構造ごとに買な り，数\%から $82 \%$ の值を示す(表 1)。ナッナ島束部の D-Alpha L (AL), AV, South Plaus, Lemadang 構造や サラワク湖合の V1，K5，L3 構造などに拉いて,炭酸が

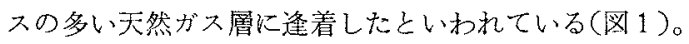
特に ESSO の D-Alpha L の天然がスは, ガス層厚 5,250 feet，ガス賦存面積 $285 \mathrm{~km}^{2}$ K及ぶ上部中新統〜 最下部鮮新統の礁石质岩以胚胎するが，67-82\%の炭酸 ガスを含えでいる（SANGREE, 1981)。マレーシア東部 沛合にある Semangkok 油田の随伴ガスは, 約 $27 \%$ 炭 酸がスを含有する（WAN and SOONG, 1984)。また，
タイ湾(シャム㴒)のB(TP) 構造やニニネングループ拄 1 によって開発されたタイ沖ガス田の炭酸がス含有量は, それぞれ平均 $32 \%$ と $15 \%$ である(ACHALABHUTI, 1981)。

一方，ナッナ島西部の Udag 油田, Tembang, Bawal 構造やサラワク沖合のガス田群 F6, E8，F23，E11/ F13，M3 構造の天然がスは，炭化水素を主成分とし，わ ずかに数\%の炭酸ガスを含むのみである（SCHERER， 1980; CROSSEY 5, 1982)。

これらの天然がス中に存在する炭酸ガスの成因や集積 に関する地質学的考察（例之ば，HOLMQUEST，1965） は，炭化我素の生成・移動・集積の研究に比べて，著し く少ない。東南アジア地域では, SANGREE (1981) が D-Alpha L 構造の炭酸ガス起源を深部の火成活動に由

注 1 Unocal Thailand Inc., 三井石油開発㑣站よび東南アジア石油開 発 
来するとしたのに対して，EYLES and MAY (1984)は 礁石灰岩膡の下位に発達する中部中新繶のArang層がそ の根源岩であるらと述べた。日本に拉いても新潟平野の ダシーンダフ層準の樑層ガスに炭酸ガスが多いことが助 らかとなり，その起源をどう考觉るか興味ある問題とな っている(坂田ら，1985)。

小論では，タイ湾で開発された Platong ガス田に打汗 る炭酸ガス含有量の水平的, 整淔的変化や地質層序との 関連性を求め，この地域に認められる幾つかの地質的諸 現象を基炡，酸ガスの成因と集積の仮説モデルを推定 した。

\section{Platong ガス田の地質概要}

現在，タイ湾の汪隹中央部比 Platong; Erawan, Satun と Baanpotの4つのガス田があり，日産的3.6意 feet $^{3}$ の 天然ガスと約 $16,000 \mathrm{bbl}$ のコンデンセートを生産してい る(啁 2)。これらのガス田は Pattani Trough と呼ばれ る第三系堆積盆地の西部に位置し，南北方向に雅行する 背斜群で第三紀初期加更新世至る断裂運動と緩やか な裮曲運動によって形成された。これらの構造の両翼部 は，多数の正断層によって包られ，それらの断層の一部 は明らかに基盤を切り，また海底付近まで達している。

夕人湾に和忷第三系の地質層序は，WOOLLANDS and HAW (1976) や ACHALABHUTI (1981) Kよって 堆積輪䞤と花粉層序を基飞，現世加ら中新怗後期に至る 上部層，中新世中〜前期の中部層および漸新世の下部層 に区分されている。しかし，検討地域の第三系には詳細 な年代層序や地層対比に有効な微化石が浪とえど産出し

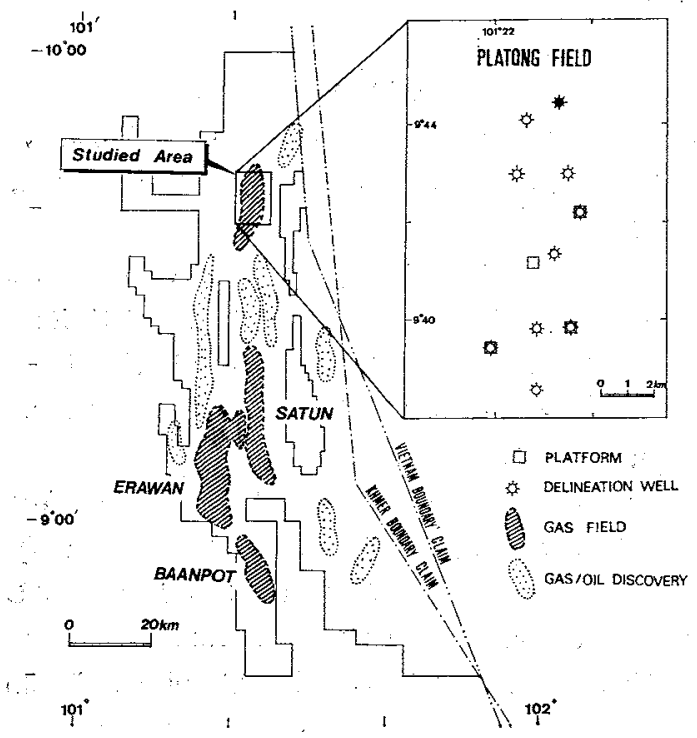

図 2 タイ湾のガス田扣よず搆造位置図
ないため，特改的な梭層击線から得られた鍵層 (Marker M1 M4）を基準に地層対比を行い，便宜的に 5 層準に 区分した。佐々木（1985）の層序区分と此較すると，I 層は上部層, II 序は中部層の雑色頁岩相, III $\sim$ 層は叶 部層の死色頁岩相と下部層に活ぼ相当する。

本ガス田の天然ガス虫，深度 4,000 9,000 feet 間に 発详する中部層と下部層の砂岩に賦存し，背斜・断層・ 層位型封塞鉱休和よびそれらの複合型封塞鉱床と考兄ら れている。石英粒に富む細〜中粒砂岩は，良好な貯留岩 であるがやや連続性に之しく，層厚 40 feet 以内のもの が卓越する（藤原ら，1986）。

\section{3. 炭酸ガスの含有量とその分布}

Platong ガス田に拈いて，多数のガス層から採取さ和 た天然ガス中の炭酸がス含有量は，一般に樑度とともに 增加する傾向にあ，媣度 5,000 feet で約 $5 \%$ 注 2 , 9,000 feet で約 $30 \%$, 平均 10-20\% の值を示す(図 3)。 しかし，6,000 feet 以深の層準以は炭酸がスの含有量が

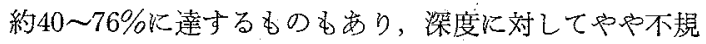
則な分布をしている。

図 4 亿地質層序と炭酸ガスの含有量の関係を図示す る。それぞれのガス層の層序的位置は，各層準( I V 層）の層厚と鍵層（M1〜M4）加ら各ガス尿までの層厚 との此を求め，標準地質柱状図に内挿した。地質層序に 対する炭酸ガス含有量の变化は，深度分有と同様に下位 層に向加て次第比大きくなる偵向を示す。一方，40〜 $76 \%$ 炭酸がスる含むガス層はV V 層とV層に認められる

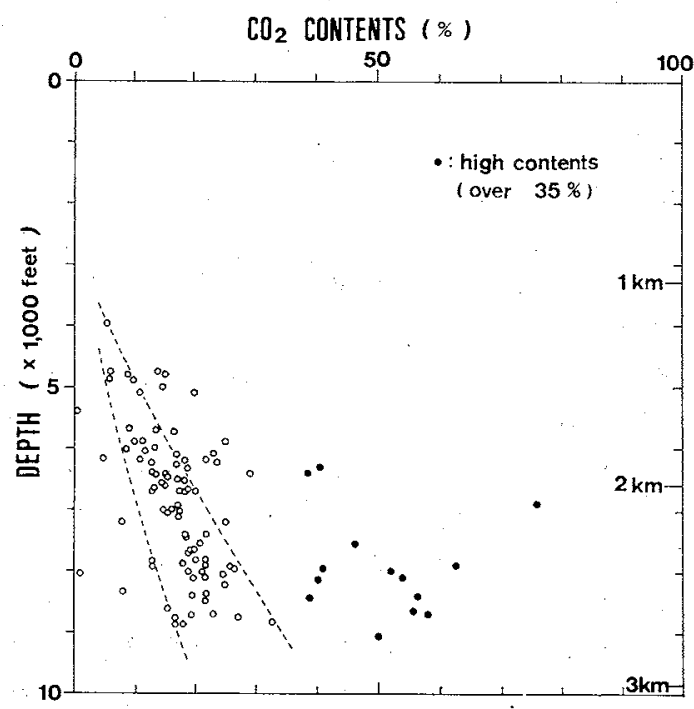

図3 Platong ガス田に拈ける炭酸ガス含有量の深 度分布

注 2.モル百分率 


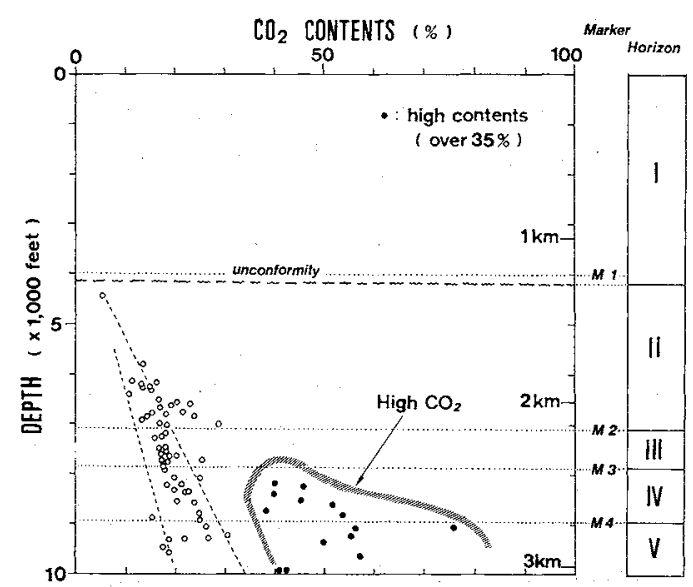

図 4 Platong ガ大田の炭酸ガス含有量と地質層序 関係

が，炭酸ガスの少ないがス層（因 4.破線内）と混在す る。この混在現象はる特定の層準や岩相が直接的に炭 酸ガスの濃集に関与したものではなく，むしろ他の地望 要因炕よるのと考觉られる。

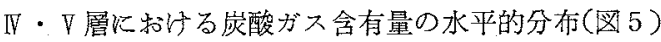
を見ると，40\%以上の岩酸ガスを含さがス痛は，Platong 構造の北西部に限定さ礼，北北西一南南東方向に細長く 延びている。そして，東部叔よび 南部に向かって炭酸がスの含有量 は急激に減少している。

この炭酸がス含有量の水平的・ 垂直的変化を検討するため，各坑 井に打ける炭酸ガスの含有量を図 6 に示した。本ガス田北酉部の嫔 井 Well 5〜Well 9 には炭酸がス を多く含もがス風が $\mathbb{V} ・ \nabla$ 層に集 中して分布している。特儿，坑井 Well 6 では炭酸がスに富むがス 層が層序的火最も若い $\mathrm{N}$ 層上部类 で及んでいる。この高含有量の層 準は，北西部から東部等よび南部 に向办って下位眉へ移動し，東部 の Well 1〜4 や南部の Well 12〜 14 では $29 \%$ 以内の平均的值とな り，側方に変化している。票た， 炭酸ガス含有量の垂直変化は，炭， 酸ガスの多い坑井に㧤いて顕著 で，Well 11 ではマ層上部の炭酸 ガス含有量が50\%であるのに対し て， N 層最下部のそれはわずかに 16\%と少ない。
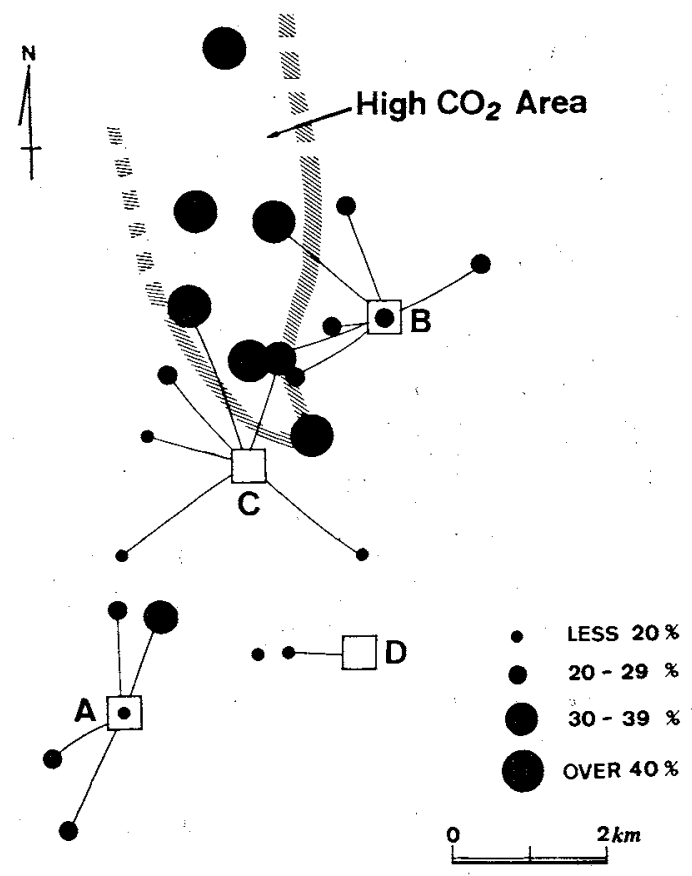

図5 IV・V層に甜りる炭酸ガス含有量の水平分布
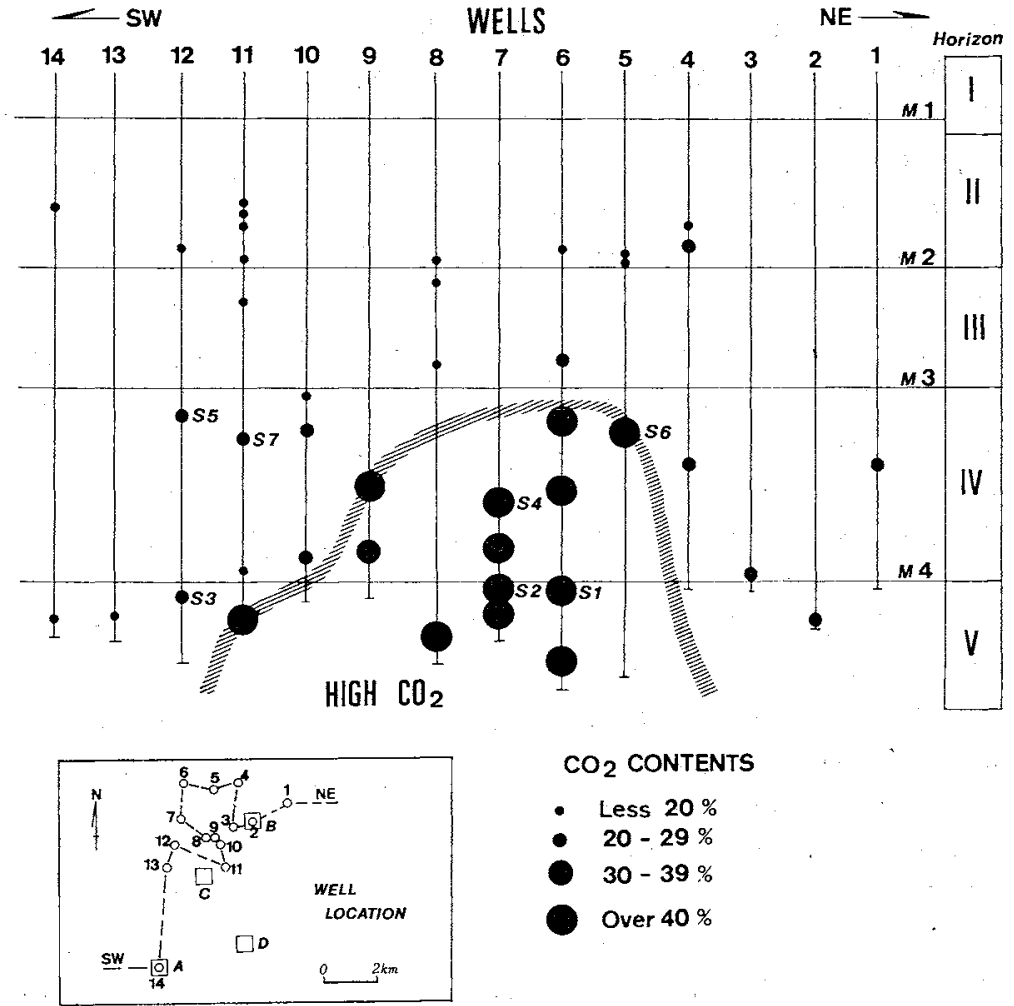

$\mathrm{CO}_{2}$ CONTENTS

- Less $20 \%$

- $20-29 \%$

$30-39 \%$

Over $40 \%$

図6、各坑井に打ける炭酸がス含有量の水平および重直分布 


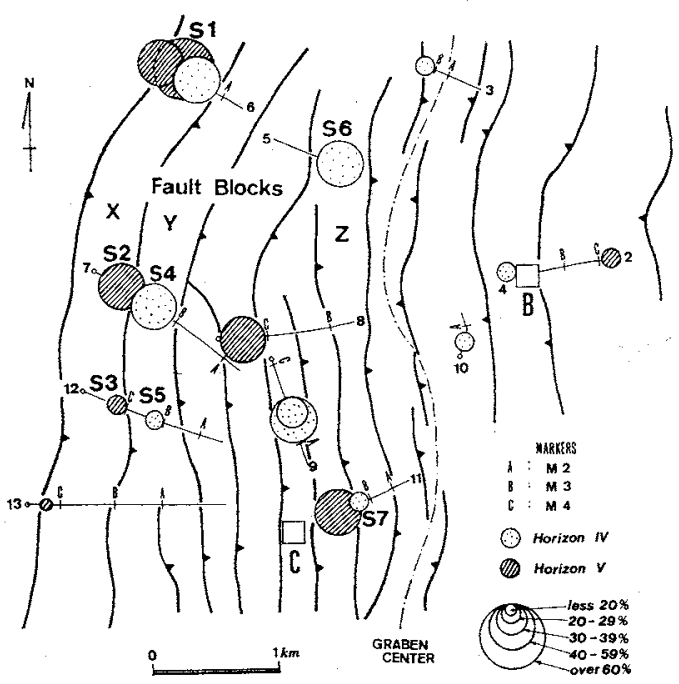

図 7 V V V層に和ける炭酸ガス含有量と断層ブロック 䦭係

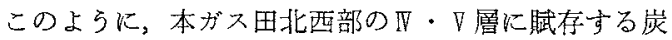
酸ガスを多量に含䑙ガス層は，南北方向に伸長なドーム 状分布を示し，明らか以地質層序と斜交する特異な分布 形態をしている。

藤原（1985）などによって記述されているように， Platong ガス田を含むタイ湾の集油構造は，南北力向の 正断層によって地層が構造の軸部（Graben Center）に 向放って階段状落ら込み，ブロック化され，しばしば 断層封塞型鉱床を形成している。そのため，各がス層が どの断層ブロックにあるがの空間的位置を考罳して， 同一断層ブロック内に和ける炭酸ガス含有量の変化を椮 討した(应 7 )。

、膡に和いて，断層ブロックーX省掘削した坑州は， Well 6,7,12と13である。その内, Well 6 の $\mathrm{S}-1$ ガス 層 (以下，S-1層）Well 7 の-2 層および Well 12 の $\mathrm{S}-3$ 層は，図6で示されるごとく， 7 層最上部に発達す る砂若層で層序的に汪济同一時代のるのとみなされる。 しかし，そこに含まれる炭酸ガスは，S-1層で76\%， $\mathrm{S}-2$ 層で $57 \%$ ，S-2層の南約 $800 \mathrm{~m}$ にある S-3 層では 26\%と減少している。また，V層に和いて，断層プロッ クーYにある S-4 層と S -5 層，および断層ブロックーZ にある S-6 倜と S-7 層は若干層位的に上下関係にある ものの，炭酸ガスの含有量は北部から南部へそれぞれ $52 \% \rightarrow 25 \% ， 46 \% \rightarrow 21 \%$ と減少している。

以上のように，炭酸ガスに富导ガス層は必ずし子特定 の断層ブロックに限定されているのではなく，一のの地 理的な搪がりをしている。そして，注目される事害は次 章で記述されるように，炭酸ガス含有量の大きいガス層
が搆造軸部（Graben Center）より西翼部，すなわち， 東㑯斜の断層区域に分布していることである。この分布 現象は炭酸ガスの起源やその移動・集積機楧を推察する 上で重要な意梠を持つるのと考えられる。

\section{4. 炭酸ガスの成因}

加藤（1976）が紹介しているょうに，天然がス中の炭 酸ガスの起源は多様であり，それぞれのガス田における 火成活動, 地熱活動, 構造運動, 炭酸塩岩, 堆積岩中の ケロジェンタイプと熟成度，地層水の性状などの地質現 象之滵接に関連している。その起源に関する諸説を列挙 すると，大きく無機成因説と有機成因説に区分される (FARMER, 1965; TISSOT and WELTE, 1978)。 無機成因説

(1) 炭酸塩岩の変成

(2) マグマ性ガスの上方移動

（3）地層水加らの游離

有機成因説

（4）有機物の微生物分解

(5) タイプッジェンの熱分解

(6) 石油・可然性ガスの熱的変質

(7) 鉱化溶液による炭化水素の酸化

Platong ガス田の炭酸がスが上記のいずれに起因する 可能性が大きいか幾つかの地質学的特徽から推察する。

\section{1 炭酸塩岩の接触変成}

炭酸がスが天然がスの主成分をなす場合，その起源の 多くは，炭酸塩岩が火成岩の进入によって熱分解された 結果生成したものであり（LEVORSON，1954など），炭 酸塩岩の変成が炭酸がス発生の主要原因であると考兄る のが最も合理的である(加藤，1976）。

Platong ガス田周辺の3 次元反射地震記録と多数の試 探掘井や生産井の坑井資料から判断すると，本地域には 第三系を貫く火成岩体は，これ委でにまったく認められ ていない。さらに，古期堆積岩，変成岩や白画紀末剘の 花誾岩類を不整合火覆う第三系は，主に泥岩砂岩層から 成り，わずか比 feet のドロマイトや石灰岩の薄層を 挾むのみである。ただ，堆積盆地の深部に厚い炭酸塩岩 が発達する可能性も残されているが，本地域に第三紀の 火成活動が認められないことから火成岩の迸入に伴ら炭 酸塩岩の接触変成による炭酸ガスの生成は，ほと九ど無 視してbさしつか完ないであるう。

\section{2 断層による無機生成ガスの上方移動}

堆積岩中で生成された有機生成ガスや地下深部にめる 無機生成がスは，断層，破厒芇，フラクチャなどの断裂 系を通って上万移動する。

すでに述べたように，タイ湾のガス田構造に発達する 


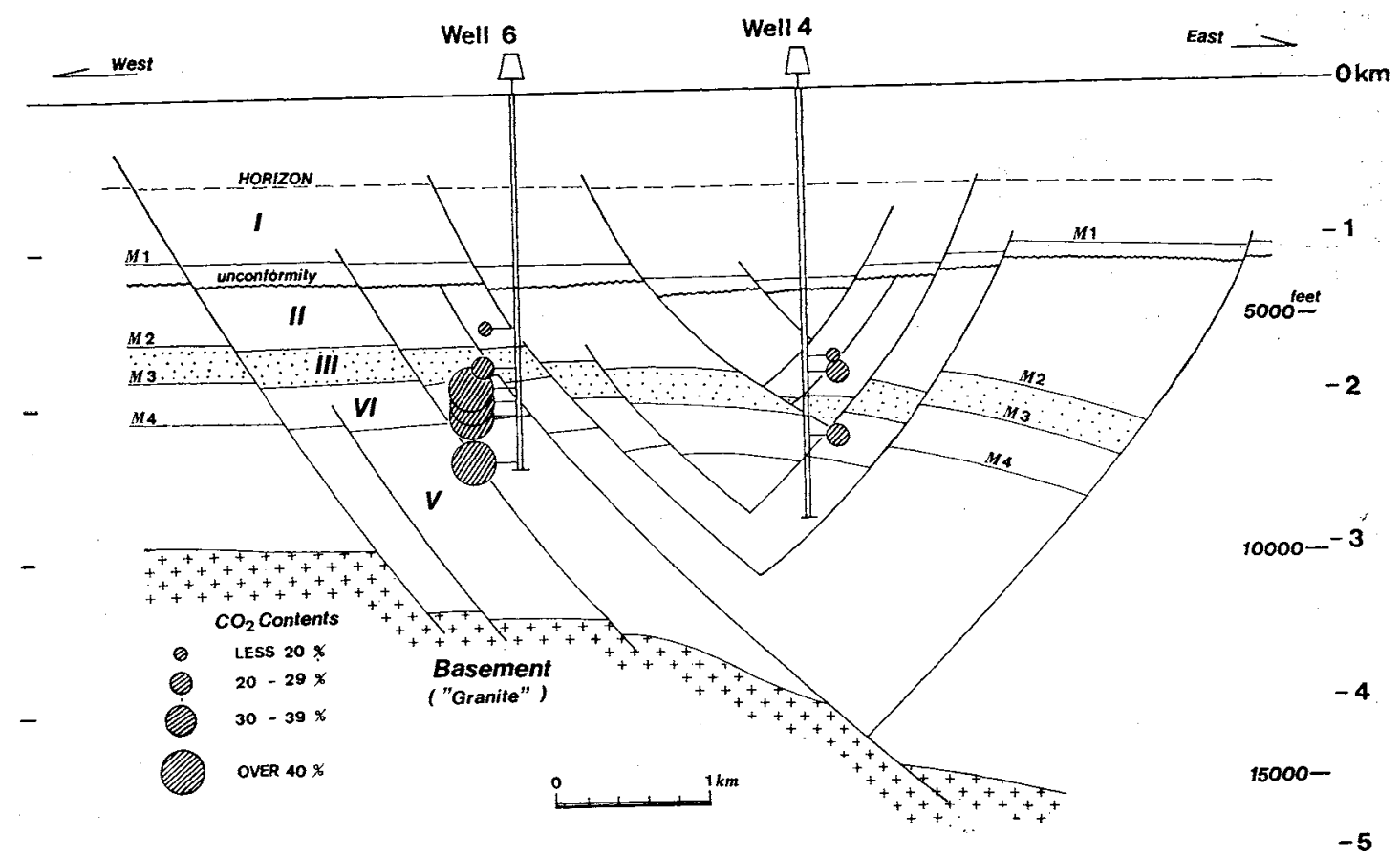

図 8 東西地質断面図と炭酸がス含有量の側方変化

多数の断層は，白要紀末期以後の断裂運動によって形成 され，天然ガスやコンデンセートの移動・集積に深く関 与している。

图 8 は 3 次元反射地震記録断面と坑井資料を基に作成 した Platong ガス田の東西地質断面である。本構造の西 翼部に位置する坑井 Well 6 は，41〜76\%の炭酸ガスを 含父数条の東傾䣄の正断層が通っている。一方，坑井 Well 4 は構造の軸部に方り，多くの東末たは西㑯斜の 正断膡に切られているが，炭酸がスの含有量は16〜23\% と少ない。断層の形状を比較すると, Well 6 を通る東 傾斜の断層が基盤を切るのに刘して，Well 4 周辺の断 層はいずれも第三系中で消隇している。これらの断層の 差異は若酸ガスの量を規制していると推定される。基盤 を切る断層区域 (本構造西部) に炭酸がスの濃集带が集 中する現象は，地下深部に存在する無機生成ガス(マグ マ性ガス）がこ机らの断層に沿って上移動したという 可能性を示す。

基盤を切る断層が炭酸ガスの上力移動の役割を果たし ていることは十分に考光られることであるが，図７亿示 すごとく，同一断層ブロック内で炭酸がスの含有量が急 変する事実をどのよう《解释寸るかが問題として残さ能 る。菊川・佐々木 (1985) に上ると，タイ湾のガス田に 発達する断層はそれぞれ成長・消減の時期や運動量が違 い,さらに同一断層に和いても主要な活動時期と運動量 が場所火よって罢なる複雑な動きをしているという。こ
の断層の動きと炭酸がス会有量との関係を求めることに よって，相対的な無機生成ガスの上方移動量が推定でき るか子ししない。

\section{3 地層水からの遊離}

地層水の化学的・物理的性質は，水の起源，続成作 用，風化作用，天水・海水の浸入ゃ火成活動などの数多 くの因子に支配されている。地層水の溶解無機成分の種 類と濃度は，唯程環境による水の起源と続成作用を反映 している。

有機物の徽生物分解や熱分解などによって生成された 炭酸がスは，地層水中に炭酸水素イオン $\left(\mathrm{HCO}_{3}{ }^{-}\right)$とし て溶解し，その溶解度は生力・温度の增加につれて增大 ナる。

本ガス田の $\mathrm{HCO}_{3}^{-}$濃度は, 約 $1,000 \sim 5,000 \mathrm{mg} / l$ で，地層水の主要な陰イオン成分をなす。目本の油时・ ガス国水の $\mathrm{HCO}_{3}{ }^{-}$濃度（石油鉱業便覽，1983）が，塩 素イオン $\left(\mathrm{Cl}^{-}\right)$濃度と比べて相刘的に著しく少ないのに 対し，本ガス田のそれは忹ぼ同程度含をれている。そし て，一般に地層の圧力・温度の減少や天水の浸大に上る 酸化バクテリア作用や酸素の供給によって, $\mathrm{HCO}_{3}$ - 濃度 の高い地層水から炭酸がスが遊離・発生することが知ら れているが，天然がス中の炭酸がス含有量と地層水の溶 解無㙨成分の濃度, 特に $\mathrm{HCO}_{3}{ }^{-}$との相関性は, Platong ガス田の地層水の分析值が少ないため明らかでない。

しかしながら，炭酸がスの多いがス層や高密度浑質岩 
中の眇岩層から採取された地層水は， $\mathrm{Cl}^{-}$濃度が約 300 ppmと低く，同一層準の地層水の1/10で淡水に近い。こ

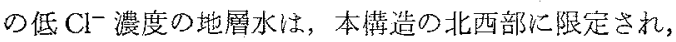

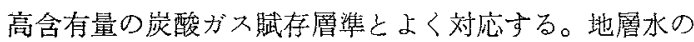
塩分濃度は，天水の浸入，倠積岩の続成過程で粘土鉱物 の層間水の脱水やマグマから供給された水などによって 低下する。

Platong ガス田で恐められた低塩分濃度の地層水がい かなる地質琴象による希数かを解明するための十分なデ 一タは得られていないが，仮りに天水の浸入による地層 水の希釉考光た場合，低塩分濃度の地層水が不整合面 より数 1,000 feet 下位の媣部層準のみに存在すること， 扣よび砂岩の不連続性から判断して，その可能性は湶と んぞないであるう。本た，堆積環境，岩相や压密過程の 類似性和よび特買な局部的分布と高孷酸ガス賦存層準々 の対応性から見ると，粘土鉱物の層間水による希釈と考 えるよりも，毛しろ，地下深部から供給された水溶液に

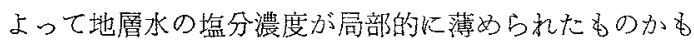
しれない。もし，この特暴な地層水と炭酸ガス賦存状沉 の関係が明確になれば，炭酸ガスの起源を推定する上で 重要な情報となるであるら。

\section{4 タイプII ケロジェンの熱分解}

前章では特に Platong ガス田に認められる高含有量炭 酸ガスの分布状況について述べたが，Pattani Troughの 試探掘井扛よび開発井から採取されたにとえどの天然が ス中には数\% 20\%程度の炭酸ガスが含まれ，堆積盆地 の規模で広域的に存在する。この炭酸ガスの広域分布 は，その根源が堆積盆地内に普遍的にあることを示す。

多くの文献 (TISSOT and WELTE，1978なぞ）で論

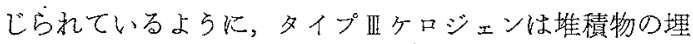
没続成過程で熱的変質を受仔乾性がスに富导炭化水素之 岸酸ガスを生成する。

Pattani Trough に拈梳第三系の有機物は，主に陸源 性で少量の腐泥質と草本質ケロジェンを含路木部質・石 炭質ケロジェン（タイプ蚛ケロジェン）から成り，不整 合以深の II $\sim \nabla$ 層では熟成度指整の $T_{\max }, T A I$, ビトリ ナイト反射率とも熟成带 $\left(R_{0}=0.5 \sim 1.3 \%\right)$ を示す。 この地化学データによれば，本地域に賦存する天然ガス や原油は，熟成艼にあるタイプ吕ケロジェンの熱分解に よって生成されたと考方られる。すなるら，堆積盆地の 規模で普蒚的に存在する峤酸ガスの多くは，成因説(4)の 微生物により生化学的に生成されたるのでなく，烓積後 の埋没続成過程で受けた有機物，特にタイプ岓ロシェ ンの熱分解で炭化水素ととも火生成され，貯留砂岩へ移 動・集積したものと考光られる。

堆積盆地の樑部 (過熟成帯)で石油やメタンが熱的变
質を受けて，炭酸ガスの発生（成因説6）が起きる可能 性もあるが，現時点では明確でない。

3章で記述した地犋層序に対する炭酸がス含有量の变 化（図 4 の破線内）はチロジェンの熱分解説に基つけ ば，次のように解釈でさる。主に赤褐色〜雑色泥岩から 成る II 噟は，正層以深の層準に比べて有機物の量が極め て少ない。そのため，I層の炭酸がスの発生量は少な

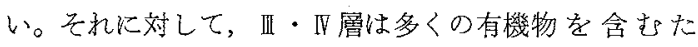
め，I層上り多くの炭酸がスを発生する。もし，崖酸力 不発生量が地層水の溶解量より大きければ，遊離した荻 酸ガスは貯留砂岩層へ移動し，相対的比天然ガス中の炭 酸がス含有量を大きくする。さらに，、層の有機物は， 量的に多くかつ石炭質ケロジェンが卓越するため，木部 質ケ口ジェンの多い目・層上りもより多くの炭酸がス 発生する。このよう飞，倠積岩中の有機物量とタイプ の差は，天然ガス中の炭酸ガス含有量を規制する。

\section{5 地熱・鉱化溶液}

現世の火山・地熱地带に叔ける滲出ガス中の炭酸ガス 量は極めて多く，火山性ガスの主要産物である。

火山地帯のないタイ国に和いても, 非火山性の温泉・ 地熱地带がタイ北部のチェンマイ周辺やマレー半島に知 られている。これらの地熱地帝は，花崗岩地域の断層， 破执带や㲅机目といった断裂系沿って分布し，周辺の 地層は温泉变筫作用を受けている(高島・河田，1981）。 地熱地带と鉱化溶液扎よび炭酸がスの間には密接な関係 が书ると考光られる。

地質断面図（図 8) で明らかなように，Platong 程造 に拈る基盤（たぶん花崗岩佮）は，東问きの正断層に よってその東側が急激に陌没している。この基盤の構造 形態がチェンマイ周辺の温泉・地熱地带の基盤構造に類 似することから，Platong ガス田の基盤付近にる潜在的 な地熱活動の可能性が推定される。もし，地熱活動の場 が局部的炕すたと仮定すれば，基盤内発達する断

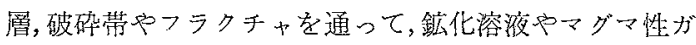
又等が地下深部から上昇してきたであるう。そして，鉱 化溶液が堆積層中に胚胎する炭化水菜と接触すれば，炭 酸ガスは崖化水素の酸化によって形成される(FARMER, 1965)。

Platong 棈造に放いて，上記の見解を具体的かつ直接 的に証明する十分なデータは得ら机ていないが，鉱化溶 液による岸化水素の酸化説を暗示する二・三の特徴的な 地質現象力認められる。

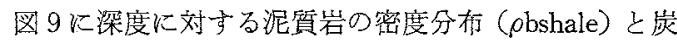
酸ガスの含有量との関係を示した。なお，泥質岩の密度 は密度検層 (FDC) から求めた。炭酸がスの含有量が29 \%以下の坑井（Well 2，12，13） に括ける泥質岩の密度 


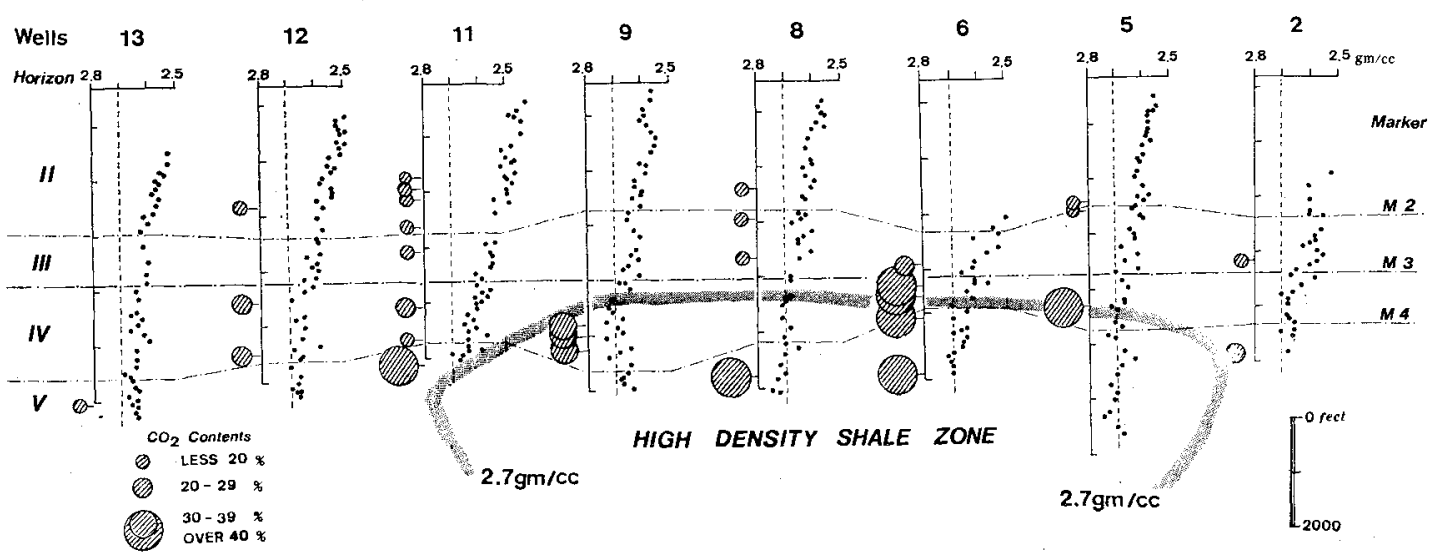

図 9 泥質岩り密度と炭酸ガス含有竸り相関性

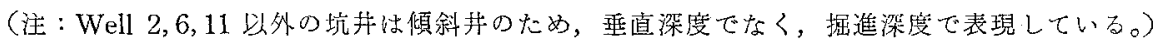

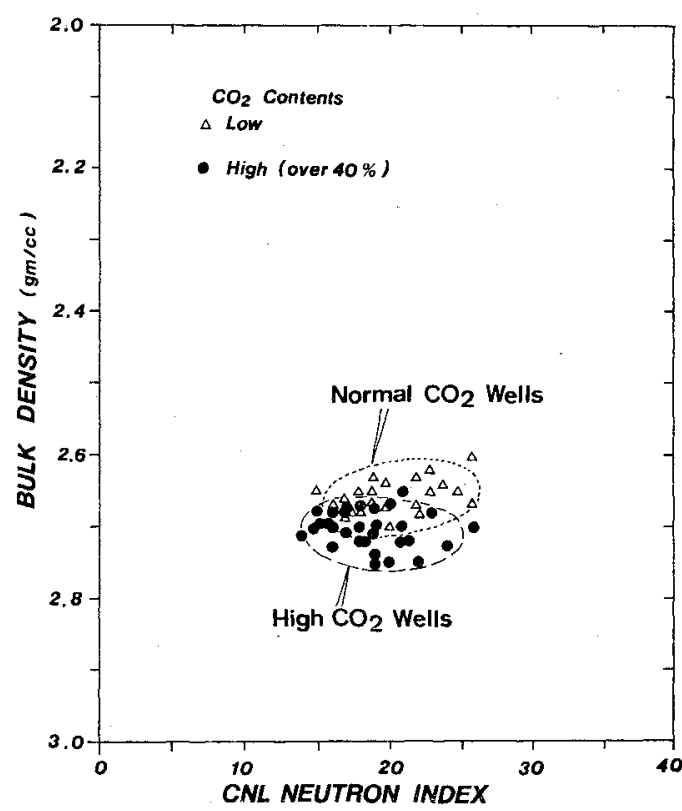

図10 V層に扣计る泥筫岩の特性

は，最大值 $2.65 \sim 2.69 \mathrm{gm} / \mathrm{cc}$ であるに対して，35\% 以上の炭酸がスを含蚂坑井 (Well $5,6,8,9,11$ ) では, $2.70 \mathrm{gm} / \mathrm{cc}$ を超生高密度の海留岩が卓越し，㭙飞 2.75

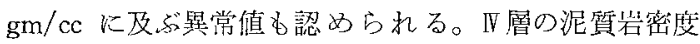
在比較すると，炭酸がス含有量の小さい坑投 Well 2,11 〜13 では $2.60 \sim 2.68 \mathrm{gm} / \mathrm{cc}$ であるが，炭酸ガス含有 量の大きい坑井 Well 5 9 9゙は $2.70 \sim 2.74 \mathrm{gm} / \mathrm{cc}$ 大きく，蓍しく硬化している。この $2.70 \mathrm{gm} / \mathrm{cc}$ 以上の 高密度泥質岩は，Well 8 とWell 9 で目周上部にまで及 び，明らか地筫層序と斜交する。

泥質炭の密度 (Bulk Density) と中性子孔吵率 (CNL, Neutron Index) の関係办ら V層の泥質岩の差異を求め
ると，炭酸ガスの多いガス層が賦存する泥質岩性，炭酸 ガス含有量の小さい泥質岩より密度で平均 $0.05 \sim 0.07$ $\mathrm{gm} / \mathrm{cc}$ 大さく, 中性子孔陵率で平均 $3 \sim 5 \%$ 小さく, 全 体的に左下八移動している(図10)。この特異な高密度泥 質岩は，本がス田の北西部に分布し，炭酸ガスに富むガ ス層の賦存する区域と一致する。

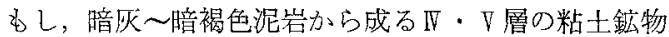
組成がカオリナイト，イライト，モンモリロナイトによ って構成されているとすれば，それぞれの粒子密度は $2.60 \sim 2.68 \mathrm{gm} / \mathrm{cc}, 2.64 \sim 2.69 \mathrm{gm} / \mathrm{cc}, 2.2 \sim 2.7 \mathrm{gm} / \mathrm{cc}$ であり (RIEKE and CHILINGARIAN, 1974), 泥澌岩の密 度が $2.7 \mathrm{mg} / \mathrm{cc}$ を超えることは住とんどない。カッテン グスで黄鉄鉱の存在が報告されているよらに，この高密 度泥質岩には粒子密度の大きい粘上鉱物（例点ば緑泥石 $2.79 \mathrm{gm} / \mathrm{cc}$ ) や重鉱物が多量儿含まれていると推定され る。北西部の極く限られた区域に認められる密度の大き いこれらの鉱物は，泥質岩の堆積時に濃集されたと考觉 る上りむ，导しろ他の地質的要因によって堆積後に二次 的以晶出したと考光方方が合理的である。

この上うに，高密度泥質岩や低濃度地層水の分布層準 と区域が孷酸がス含有量の大きいガス層の倵存層準と分 布区域に対応することは與味深い現象である。これらの 相関性は，共通の地質的要因によって形成されたことを 示与。FARMER（1965）の鉱化溶液説に往えば，地下深 部から断裂系に沿って上昇してきた鉱化溶液は，浑質出 の特性変化，地層水の肴薄化之炭化水素の酸化阙与し， 多量の炭酸ガスを発生さ好たと解釈される。

\section{5. 仮説モデル}

前章で記述した Platong ガス田に打ける地質的諸現象 を基见推定される炭酸がスの成因とその濃集機構のそデ 


\section{MODELS}

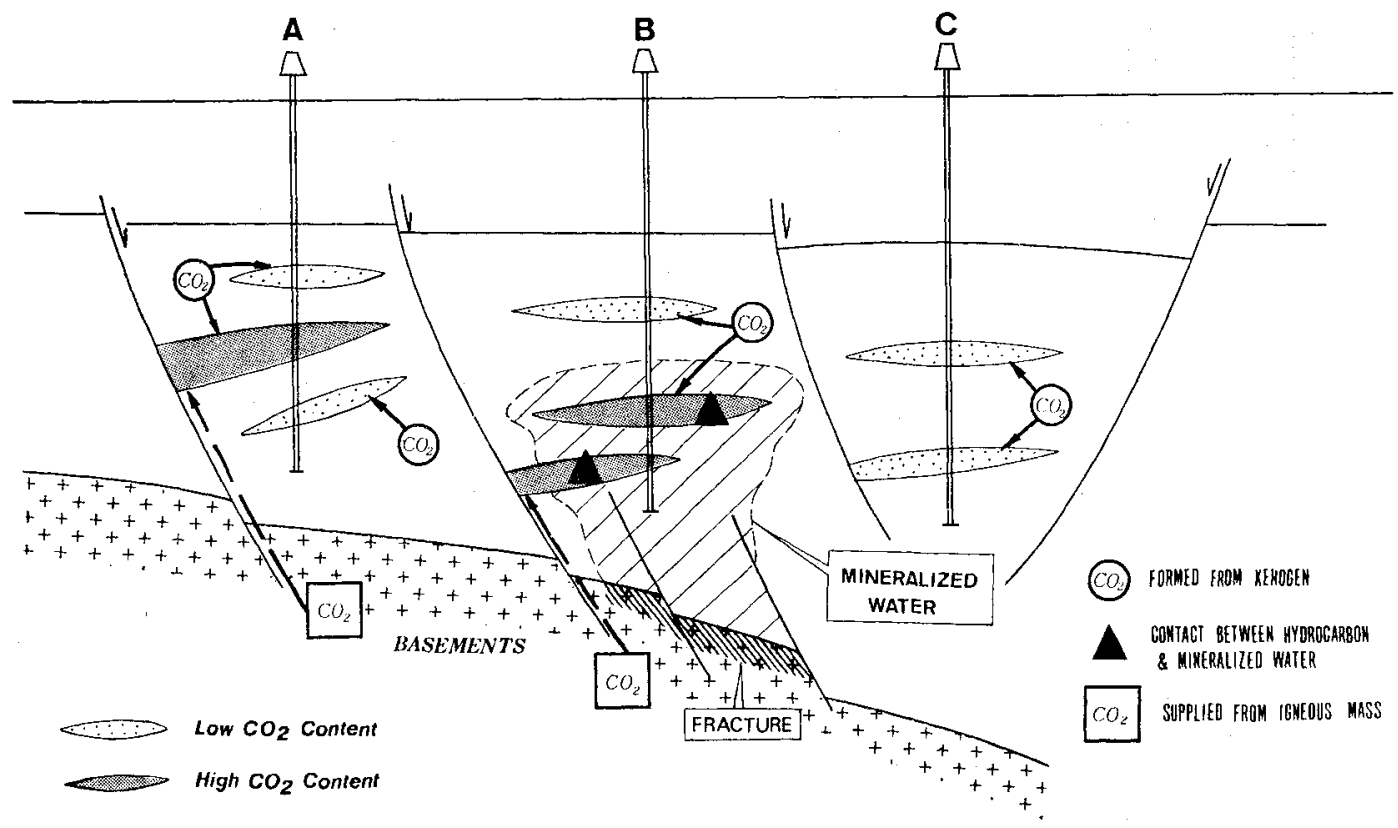

図11 Platong ガス出に扣ける炭酸ガスの起源（仮説モモ゙ル）

ルは, 次の3つK要約される(図11)。

(1) タイプII ケロジェンの熱分解

（2）地下深部の無機生成ガスの上方移動

(3) 鉱化溶液による炭化水素の酸化

可然性ガスに随伴する若干の炭酸ガスは, 倠積物の埋 没続成下で受ける有機物，特にタイプ III ケロジニンの熱 分解によって，炭化水素とともに生成され，貯留岩に移 動・集積したと考えるのが最め合理である(モデルC)。 しかし，炭酸がスが天然がスの主成分をなす Platong ガ 大田北西部の異常带の場合，有機物の熱分解説に加えて 次の炭酸がス成因説を考完る必要がある。

その一つは，マグマ性の無機成因ガス中に含をれる炭 酸ガスが基盤を切る断層に沿って上方移動し，貯留岩以 濃集したモデルAである。天然ガス中の希ガス組成や炭 酸ガスの炭素同位体組成の分析を行っていないため，本 構造北西部の高含有量炭酸ガスがマグマ性起源であると 断定できない。しかしながらタイ湾で掘削されたある坑 井に特ける炭酸ガスの炭素同位体組成は，有機物の熱的 変成によって生成されたるのと明らかに異なり，火成活 動や地下樑部から供給された炭酸がスであるといわれて いる。

もら一つのモデルは，前章で述べたよらにさまざまな 規模の割れ日，断層や破砕帯を通路として，地下深部よ り上昇して来た鉱化溶液が貯留岩中以集積していた炭化

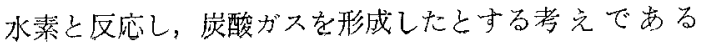

(モデル B )。

いずれにしても，Platong ガス田の天然ガス中に含ま れる炭酸ガスの起源は，上記のケロジェン分解説，マグ マ性ガスの上方移動説挹よび鉱化溶液説が有力で西る が，あくまで間接的な地質現象に基ら゙く考察である。今 後の課題として，メタン，エタン，炭酸ガスの炭素同位 体組成や $\mathrm{He}, \mathrm{Ne}, \mathrm{Ar}, \mathrm{Xe}$ などの希がス成分，泥質岩の 粘土鉱物・重鉱物データを加它大総合的検討を行い，炭 酸ガスの起源を明確にする必要がある。

\section{謝 辞}

本研究に際して，凟料検討门機会を与えられ，乙の結 果の公表を許可された三茾石油開発侏常務取䋨役石原寿 夫氏之同社常務取䋨役圾本 糺氏，並びに東南アジア石 油開発侏取締役牧野登喜男氏に衰心より謝意を示す。 た，有益な助言を賜わった三井石油開発㑣操鉙部長会田 英夫氏と整図・タイプをして頂いた同社の塚原順子氏に 感謝与る。

\section{文献}

ACHALABHUTI Charan, 1981: Natural Gas Deposits of Gulf of Thailand, In M.T. HALBouTy, ed; Energy Resources of the Pacific Region, 155-166, A.A.P.G.

BrAMON, B., 1974: LNG Projects in Indonesia, Proccedings Indonesian Petro. Asso., 3rd. annual 
convention, 265-279.

COSSEY, S.P.J., W.T. VAlENTA; F. PAYOT and T.T. Ho, 1982: Seismic Hydrocarbon. Indicators in the South China Sea: Geological and Geophysical Aspects, Proceedings Indonesian Petro Asso., 11th annual convention, 335-355.

DobBin, C.E., 1968: Geology of Natural Gases Rich in Helium, Nitrogen, Carbon Dioxide, and Hydrogen Sulfide, In B.W. BEEBE, ed; Natural Gases of North America, AAPG Memoir 9, 1957-1969. A.A.P.G.

EYLES, D.R. and J.A. MAY, 1984: Porosity Mapping, using Seismic Interval Velocities, Natuna L-structure, Proceedings Indonesian Petro. Asso., $13 t h$ annual convention, 301-316.

FARMER, R.E., 1965: Genesis of Subsurface Carbon Dioxide, In. A. YounG and J.E. GALLEY, ed; Fluids in Subsurface Environments, AAPG Memoir 4, 378-385. A.A.P.G.

藤原昌史，1985：タイ沖ガス田の断層トラップについて (要旨)，石技誌，50(4)，262.

藤原昌史・前田純二・安原 清, 1986：三次元反射地震 探查法に上る含がス砂岩層の解析，石技誌，51(1)， $67-75$.

Holmquest, H.J., 1965: Deep Pays in Delaware and Val Verde Basins. In. A. YOUNG and J.E. GALLEY, ed; Fluids in Subsurface Environments, AAPG Memoir 4, 257-279. A.A.P.G.

加藤正和, 1976: 天然ガス中の炭酸ガスの起源, 石油の 開発，9(2)，31-39.

加藤正和他編集，1984：ガイドブック，世界の大油田， タ1，92-96，技報堂出版株。

菊川透・传及本詔雄，1985：三次元反射地震探查の地 質的応用(要旨)，石技誌， $\mathbf{5 0}(4) ， 268$.
LEVORSEN, A.I., 1954: Geology of Petroleum. W.H. Freeman and Company.

Mundt, P.A., 1982: Miocene Reefs, Offshore North Sumatra, Offshore South East Asia 82 Conference, Exploration III, Geology section, 1-11.

Rieke, H.H. II and G.V. ChILINGARIAN, 1974: Com= paction of Argillaceous Sediments, Developments in Sedimentology-16, Elsevier Scientific Publishing Co.

坂田 将 - 高橋 誠・星野一男, 1985: 深部火山岩天然 ガスの成因に関する地球化学的考察(要旨)，石技誌， $\mathbf{5 0}(4), 272$.

SANGREE, J.B., 1981: Use of Seismic Stratigraphy in Carbonate Rocks, Natuna D-Alpha Block Example, Proceedings Indonesian Petro. Asso., 10th annual convention, 135-152.

佳々本詔雄，1985：タイに扣忛方石油開発の現状“非産 油国加占石油自給国へ”，石油の開発之倩蓄，18(2), $20-76$.

SCHERER, F.C., 1980: Exploration in East Malaysia over the past Decade, Giant Oil and Gas Fields of the Decade: 1968-1978, AAPG Memoir 30, 423-440. 石油技衡協会編，1983：石油鉱業便覧，34-36.

高島 幘・河田清雄，1981：タイ圈の地熱エネルギー資 源，地質二ュース，(325)，16-29.

TIssot, B.P. and D.H. WELTE, 1978: Petroleum Formation and Occurrence, Springer-Verlag.

WoOllands, M.A. and D. HAw, 1976: Tertiary stratigraphy and sedimentation in the Gulf of Thailand, Offshore South East Conference, 1-7.

WAN, C.C. and J.L. Soong, 1984: Facilites Planning for the Semangkok Field-Offshore Peninsular Malaysia, 5th Offshore South East Asia Conference, Section 5, Praduction, 65-84. 